\title{
ANALISIS BENTUK FONOLOGIS DAN MAKNA ONOMATOPE DALAM VIDEO LAGU ANAK-ANAK BERBAHASA JEPANG
}

\author{
P. W. Y. Pratama, N. N. Suartini, I. W. Sadyana \\ Program Studi Pendidikan Bahasa Jepang \\ Universitas Pendidikan Ganesha \\ Singaraja \\ e-mail: wira.yudi95@gmail.com \\ nnsuartini@undiksha.ac.id wayan.sadyana@undiksha.ac.id
}

\begin{abstract}
Abstrak
Penelitian ini bertujuan untuk menganalisis bentuk dan makna onomatope pada video lagu anak-anak berbahasa Jepang. Analisis ini dilakukan berdasarkan teori semantik, onomatope Jepang, bentuk onomatope Jepang dan klasifikasi makna onomatope Jepang. Metode penelitian ini menggunakan metode pengumpulan data, dengan studi kepustakaan dan teknik catat yang kemudian data dianalisis untuk dapat mengklasifikasikan data sesuai rumusan masalah, serta mengasah keabsahan data menggunakan pustaka dan instrumen berupa kartu data. Pada data terdapat beberapa bentuk onomatope yaitu kata dasar, pemajemukan morfem (hanpukukei), pemadatan suara (sokuon),penasalan suara (haneruon) dan pemanjangan suara (chou'on). Kemudian onomatope terdapat 6 macam klasifikasi berdasarkan gambaran makna. Makna tersebut adalah tiruan bunyi benda (mono o dasu oto), suara binatang (doubutsu no nakigoe), suara manusia (hito no koe/oto), pergerakan benda (mono no ugoki), aktivitas atau pergerakan manusia (hito no dousa) dan keadaan hati atau perasaan manusia (hito no yousu/shinjou).
\end{abstract}

Kata kunci : onomatope Jepang, bentuk onomatope Jepang, klasifikasi onomatope Jepang.

要旨

この研究の目的は、日本の子供の歌のビデオでオノマトペの形と意味を分析すること です。この分析は、意味論、日本語の言語音、日本語の擬音語、日本の擬音語の形成、 日本の擬音語の意味の分類、およびデータ収集の配列を研究結果に提示する定性的研 究モデルのフレームワークを使用しています。この研究方法では、データ収集方法を 使用し、文献調査と記録された手法を使用して、問題の定式化に従ってデータを分類 できるようにデータを分析し、データカードの形式のライブラリと機器を使用してデ ータの有効性を高めます。見つかった結果には、日本の子供の歌のビデオにオノマト ペという言葉の意味が含まれていました。子音文字データには、ソクオン、ハネルオ ン、シューオンのタイプがあります。擬音語には、その意味の記述に基づいて 6 種類 の分類があります。意味は、モノをだすおと、どうぶつのいきごえ、ひとのこえ/おと、 もののうごき、ひとのどうさ、ひとのようす/しんじょうです。

キーワード：日本語のオノマトペ、日本語のオノマトペの形、オノマトペの種類 


\section{Pendahuluan}

Dalam setiap rutinitas kehidupan manusia selalu menggunakan simbol atau lambang yang merupakan salah satu satuan-satuan bahasa selain kata (Chaer, 2007: 39). Banyak ahli linguistik dan ahli filsafat telah memikirkan antara lambang bunyi dan maknanya. Hal tersebut menuntun penelitian ini kepada teori simbiolisme bunyi, yang di mana bidang cakupannya adalah onomatope. Onomatope merupakan tiruan bunyi dari berbagai macam bentuk bunyi yang memiliki kemiripan antara tulisan dan bunyi yang ditandakan maka onomatope bersifat arbitrer yang memiliki arti bahwa tidak ada hubungan wajib antara lambang bahasa (yang berwujud bunyi) dengan konsep atau pengertian yang dimaksud oleh lambang bunyi tersebut, dapat juga diartikan bersifat berubah-ubah / tidak tetap dan dikategorikan sebagai simbol. Onomatope adalah penamaan benda atau perbuatan dengan peniruan bunyi yang diasosiasikan dengan benda atau perbuatan itu (Harimurti, 1989:116). Onomatope pun menggambarkan situasi atau gambaran yang terjadi tanpa penjelasan yang rumit dan panjang agar pembaca langsung mengerti akan suatu kondisi yang sedang terjadi. Pakar semantik memastikan bahwa setiap bahasa mempunyai kata-kata onomatope. Peniruan bunyi tersebut tidak hanya mencakup suara hewan, manusia atau suara lainnya yang dapat didengar saja namun juga suara yang menggambarkan benda bergerak, berbenturan, maupun perasaan atau emosi manusia.

Sebagian besar onomatope dalam bahasa Jepang termasuk ke dalam fukushi atau adverbia. Fukushi adalah kata-kata yang menerangkan kata kerja, kata sifat, dan adverbia lainnya, tidak dapat berubah, dan berfungsi menyatakan keadaan atau derajal suatu aktivitas, suasana, atau perasaan pembicara (Matsuoka, 2000:344). Onomatope dalam bahasa Jepang terdiri dari giongo dan gitaigo. Giongo dan gitaigo merupakan salah satu aspek bahasa Jepang yang baik dipelajari untuk dapat menjabarkan variasi giongo-gitaigo untuk digunakan dalam kehidupan sehari-hari, dijelaskan bahwa dalam suatu bacaan, sangat pentingnya giongo dan gitaigo membantu penggambaran suatu benda, gerakan, atau keadaan sehingga menjadi terasa lebih hidup dan konkrit (Sutinah, 2011:6).

Sutrisna (2017) meneliti onomatope terkait giongo dan gitaigo melalui ilustrasi gambar pada komik. Namun penelitian ini memiliki kekurangan karena tidak ada gerakan yang dapat menjelaskan bagaimana memperagakan dan mengucapkannya untuk menggambarkan aktifitas sehari-hari terkait giongo dan gitaigo. Atas dasar itulah langkah untuk menggunakan 12 video lagu anak-anak berbahasa Jepang sebagai data penelitian ini pun menyajikan gerakan yang memperagakan aktifitas kehidupan sehari-hari, sehingga lebih mudah memahami maksud dari apa yang diucapkan.

Kajian mendalam tentang tiruan bunyi-bunyi ini bisa dianalisis dengan metode cabang linguistik yang disebut semantik. Semantik adalah bagian sistem dan penyelidikan struktur bahasa yang berhubungan dengan makna ungkapan, struktur makna, dan arti dalam suatu bahasa, dengan kata lain, semantik merupakan bidang studi dalam linguistik yang mempelajari makna atau arti dalam bahasa (Kridalaksana, 2008:216). Karakter bahasa Jepang yang unik terlihat dari maknanya.

Karakteristik yang unik dan sangat berbeda dengan bahasa Indonesia menarik perhatian untuk menganalisis makna bahasa Jepang lebih lanjut. Oleh karena itu, dengan menggunakan data giongo dan gitaigo dalam video lagu ini bermaksud untuk meneliti tentang makna bahasa Jepang melalui analisis maknan onomatope. Giongo dan gitaigo dalam video lagu tersebut sangat membantu sekali dalam menghidupkan intensitas gerakan atau keadaan yang diilustrasikan. Pada saat menonton video yang terdapat giongo dan gitaigo, maka dapat mengimajinasikan sesuatu didalamnya, walaupun kata giongo dan gitaigo singkat tetapi kuat dalam penggambaran sehingga mengesankan sesuatu tampak lebih hidup. Giongo merupakan kata-kata yang menirukan bunyi yang ada disekitar kita. Adapun perbedaanya yakni jika giongo lebih menggambarkan tiruan bunyi yang keluar dari benda mati, misalnya bunyi gunting dalam bahasa Jepang adalah 'chokichoki' dan dalam bahasa Indonesia 'krek-krek'. Sedangkan gitaigo adalah kata-kata yang mengungkapkan suatu aktivitas atau keadaan. Contoh, gitaigo dalam bahasa Jepang yakni ketika kita akan mengekspresikan tertawa puas dengan 'geragera', dan 'terbahak-bahak' dalam bahasa Indonesia, serta 'kusukusu' untuk tertawa geli dalam bahasa Jepang dan 'hihihi' untuk tertawa geli bahasa Indonesia. Dalam bahasa Jepang terutama pada onomatope memiliki bunyi-bunyi yang segmental (vokal dan konsonan), juga terdapat bunyi-bunyi suprasegmental (seperti nada, tekanan, jeda, dll), hal tersebutlah di analisis karena memiliki bentuk dan makna yang berbeda sangat perlunya memahami faktor tersebut sebagai bahasa yang dipelajari.

Faktor pemilihan penelitian ini atas dasar karena bahasa Jepang merupakan bahasa asing yang kini dipelajari dan sangat perlunya mengetahui onomatope bahasa Jepang yang kemudian bisa disaksikan melalui video lagu, sebelumnya belum ada penelitian terkait onomatope melalui video lagu, 
menggunakan video lagu lebih mempermudah memperdalam kesan pembaca, penonton atau pendengar terhadap pesan karena onomatope juga 'mengaudiokan' sebuah gambar atau objek dan melalui 12 video lagu anak-anak berbahasa Jepang ini onomatope lebih jelas karena ada gerakan yang diperagakan menggambarkan onomatope di dalam video tersebut. Selain itu penelitian ini juga memiliki faktor penting bagaimana Onomatope itu bisa terbentuk menjadi sebuah kata melalui jenis suara/bunyi yang akan dijabarkan lebih lanjut dalam isi dari penelitian ini.

Penelitian ini bertujuan untuk meneliti bunyi bahasa sebagai unsur pembentuk onomatope mencerminkan makna-makna tertentu. Langkah penelitian yang dilakukan onomatope dikelompokan dan dicari maknanya. Menggunakan onomatope dalam menyampaikan suatu informasi akan membuat pendengar mengetahui dengan jelas maksud yang ingin disampaikan oleh pembicara. Oleh karena itu, pentingnya bagi pelajar bahasa Jepang untuk mengetahui penggunaan onomatope tersebut. Dengan pengetahuan tentang onomatope, pembelajar bahasa Jepang akan dapat memahami makna dan penggunaan onomatope.

\section{Semantik}

Semantik merupakan bidang linguistik yang mempelajari makna tanda bahasa, yang terdiri atas unsur lambang bunyi dan konsep. Kata semantik dalam bahasa Indonesia semula berasal dari bahasa Yunani sema(nomina) yang berarti 'tanda' atau 'lambang'. Kata semantik disepakati sebagai istilah yang digunakan dalam bidang linguistik yang mempelajari hubungan antara tanda -tanda linguistik dengan hal -hal yang ditandainya. (Kridalaksana, 2008:216) semantik diartikan sebagai "bagian sistem dan penyelidikan struktur bahasa yang berhubungan dengan makna ungkapan, struktur makna, dan arti dalam suatu bahasa". Dengan kata lain, semantik merupakan bidang studi dalam linguistik yang mempelajari makna atau arti dalam bahasa.

\section{Onomatope}

Onomatope merupakan kata-kata yang digunakan untuk menirukan suara dari bunyi sumber yang digambarkan berdasarkan benda mati ataupun makhluk hidup. Dalam Kamus Besar Bahasa Indonesia, kata onomatope tergolong dalam kelas kata benda dan bermakna kata tiruan bunyi, misalnya, "kukuruyuk terhadap tiruan bunyi ayam", dan "citcit terhadap tiruan bunyi tikus". Onomatope seringkali digunakan dalam karya sastra sebagai bagian yang mempermudah untuk pembaca memahami lebih mendalam perasaan atau situasi yang ingin disampaikan sekaligus memperindah karyanya. Karya sastra yang sering menggunakan onomatope seperti komik, iklan, puisi, animasi dan sebagainya. Berdasarkan dengan karya sastra tersebut, Chaer (2012:44) mengungkapkan bahwa "Onomatope adalah tiruan bunyi yang merujuk pada kesan atau bunyi dari suatu benda, suatu keadaan dan tindakan". Maksudnya adalah benda atau suatu hal yang dibentuk berdasarkan bunyi dari benda yang dituju atau kesan suara yang ditimbulkan oleh benda tersebut.

\section{Onomatope Jepang}

Adverbia yang menggambarkan bunyi benda atau suara makhluk hidup disebut (giseigo), sedangkan adverbia yang menyatakan suatu keadaan disebut gitaigo. Kedua istilah (giseigo dan gitaigo) ini bisa disebut onomatope (Sudjianto 2007:168). Keduanya akan dijelaskan lebih lanjut sebagai berikut.

I. Giongo

Yoshio (dalam Sutrisna, 2017;35). Giongo merupakan kata-kata yang menyatakan suara makhluk hidup atau bunyi yang keluar dari benda mati. Giongo sering disebut juga dengan Giseigo. Bedanya adalah Giongo lebih menunjukkan tiruan bunyi benda mati, sedangkan giseigo lebih menunjukkan tiruan suara makhluk hidup. Berikut beberapa contoh kalimat dari giongo dan giseigo.

1. Giongo sebagai tiruan bunyi dari benda mati Contoh:

洗濯物から水がぽたぽたたれている

/Sentaku/ mono/ kara/ mizu/ ga/ potapota/ tareteiru.

'Tes tes. Air menetes dari pakaian yang dijemur".

2. Giseigo sebagai tiruan bunyi dari makhluk hidup

(EGG, 1994: 79) Contoh:

その教授はまじめに話していたが、聞いていた女子はくすくす笑った。 
Sono/ kyouju/ wa /majime/ ni/ hanashite/ ita/ ga/, /kite/ ita/ joshi/ gakuse / wa/ kusukusu/ waratta. „Professor itu berbicara dengan serius, tapi siswa perempuan yang mendengarkannya tertawa-tawa kecil."

(FBJ, 2013: 75)

II. Gitaigo

Onomatope kata tiruan yang menggambarkan keadaan dalam Bahasa Jepang disebut gitaigo. Gitaigo adalah kata tiruan yang menggambarkan keadaan fisik dan tindakan. Sama seperti giseigo, gitaigo dibagi lagi menjadi beberapa kelompok, yaitu gitaigo, giyougo dan gijougo. Berikut penjelasan dari ketiga klasifikasi tersebut.

1. Gitaigo sebagai kata yang menyatakan keadaan benda mati. Contoh:

洗濯機で古い毛布を洗ったら、ぽろぽろになってしまった。

Sentakuki/ de/ furui /moofu/ o/ arattara/, /boroboro/ ni/ natte/ shimatta.

„Ketika mencuci selimut yang sudah lama dengan mesin cuci, maka menjadi robek-robek'.

(FBJ, 2013: 143)

2. Giyougo sebagai kata yang menyatakan keadaan makhluk hidup atau tingkah laku makhluk Contoh: hidup.

初めて高いビールの空ふきをした時は。体ががたがたして掃除などできなかった。

Hajimete/ takai/ biiru/ no/ mado-fuki/ o/ shita/ toki/ wa/, karada/ ga/ gatagata/ shite/ sooji/ nado/ dekinakatta/.

„Ketika mengelap jendela gedung tinggi pertama kali, badan gemetaran, sehingga tidak bisa membersihkannya".

(FBJ, 2013: 123)

3. Gijougo sebagai kata yang seolah-olah menyatakan keadaan hati atau perasaan manusia.

\section{Contoh :}

高速道路が車で渋滞し、会議に遅れるのではないかといらいらした。

Koosoku/ dooro/ ga/ kuruma/ de/ juutaishi/, kaigi/ni/ okureru/no/ dewanai/ ka/ to/ira ira/ shita/.

"Saya merasa tidak tenang mungkinkah akan terlambat pada rapat karena jalan tol macet oleh mobil".

(FBJ, 2013: 83)

Baik giongo maupun gitaigo ditulis dengan katakana dan hiragana. Tetapi sering sulit membedakan antara giongo dan gitaigo. Oleh karena itu ada juga yang menggabungkan keduanya dalam menyebutkan onomatope, menurut teori Akimoto (dalam Sutrisna, 2017:36).

“このように擬声語。擬態語の両方に用いられたり、どちらか判断できなかったりする語もある のれ、これらを合わせて音象徵語あるいはオノマトペと呼ぶ.”

„Karena bahasa Jepang memiliki giseigo dan gitaigo, namun karena ada pula kata yang tidak bisa ditentukan masuk dalam klasifikasi yang mana, maka gabungan keduanya disebut onshouchougo atau onomatope."

\section{Bentuk Onomatope Jepang}

Akimoto (2002:136-137), menjelaskan bahwa giongo dan gitaigo memiliki beberapa bentuk khusus yang dapat menunjukkan keadaan seperti berikut ini.

1. Kata dasar

Bentuk giongo dan gitaigo yang hanya terdiri dari satu atau dua suku kata.

Contoh: tsu = suara serangga

Doka = menunjukkan suatu dampak

\section{Penasalan Suara}


Bentuk kata ini menunjukkan bunyi kata yang menggema yang diakhiri konsonan $/ \mathrm{n} /$ pada suatu kata atau dalam istilah di Jepang disebut haneruon. Selain itu, digunakan untuk menunjukkan bunyi benda yang ringan.

Contoh: ban = bunyi tembakan

\section{Pemadatan suara}

Pemadatan suara dalam onomatope bahasa Jepang biasanya ditandai dengan adanya huruf tsu kecil "つ" atau yang disebut dengan sokuon. Bentuk ini menunjukkan gerakan cepat, sesaat dan cekatan.

Contoh: Byu' = seorang karakter yang bergerak dengan cepat.

\section{Pemanjangan Suara}

Bentuk ini menunjukkan aktivitas dan keadaan yang berlangsung lama, atau biasa disebut dengan chou'on (vokal panjang). Vokal yang terbentuk chou'on sebagian besar adalah giongo.

Contoh: Kya- kowainamae!!

"Kyaa..nama yang mengerikan!!"

(OPBJ: $76: 8)$

\section{Penambahan Morfem-ri (リ)}

Kata dengan penambahan morfem-ri menggambarkan sesuatu yang lunak, lembut, licin, dan menunjukkan sesuatu yang perlahan.

Contoh: Noso $=$ nosori, Pelan $=$ Perlahan-lahan

\section{Bentuk Pemajemukan morfem}

Bentuk ini disebut dengan hanpukukei atau bentuk giongo dan gitaigo

yang menunjukkan ungkapan bunyi atau kegiatan yang berulang-ulang dan berkesinambungan.

\section{Contoh:}

Natsuyasumi mo ato isshuukan de owari dakara, botsu-botsu 'nigakki no junbi demo shiyoo.

"Karena liburan musim panas akan berakhir satu minggu lagi, saya hendak mulai melakukan persiapan untuk semester 2 sedikit-sedikit".

(FBJ, 2013: 137)

\section{Perubahan sebagian bunyi}

Bentuk perubahan bunyi sebagian bunyi menunjukkan sesuatu yang tidak beraturan.

\section{Contoh:}

Jugyoochuu, pecha kucha shaberi bakari shite iru joshi-gakusei ga ooi.

"Banyak siswa perempuan yang terus-menerus ngobrol dengan berisik saat kuliah"

(FBJ, 2013: 108)

\section{Klasifikasi Makna Onomatope Jepang} yaitu,

Akimoto (2002: 138-139). Dilihat dari maknanya Giongo dan Gitaigo mempunyai 10 macam jenis 1. Onomatope yang menggambarkan tiruan bunyi fenomena alam.

Tiruan bunyi fenomena alam disebut Shizengenshou.

Contoh:

雷がごろごろなった。

/Kaminari/ga/gorogoro/natta/.

"Gelagar suara petir"

2. Onomatope yang menggambarkan tiruan bunyi benda.

(EGG, 1994: 77)

Tiruan bunyi benda dalam bahasa Jepang disebut mono ga dasu oto digunakan untuk menunjukkan tiruan-tiruan bunyi yang keluar dari benda.

Contoh:

電話がリンリン鳴っている。

/Denwa/ ga/rin rin/ natte/ iru/.

"Telepon berbunyi/berdering-dering (kring-kring)"

(FBJ, 2013: 156) 
3. Onomatope yang menggambarkan suara binatang.

Tiruan Suara binatang atau dalam bahasa Jepang disebut Doubutsu no nakigoe digunakan untuk menunjukkan tiruan suara dari binatang.

Contoh:

犬がワンワンほえている

/Inu/ga/ wan wan/ hoeteiru/

"Anjing menggong-gong"

(EGG, 1994: 77)

4. Onomatope yang menggambarkan suara manusia

Tiruan suara manusia atau dalam bahasa Jepang disebut Hito no koe/oto digunakan untuk menunjukkan tiruan bunyi atau suara manusia.

Contoh:

おぎやあおぎゃあ

/Ogyaa/ ogyaa/

"Oek oek oek"

(EGG, 1994: 77)

5. Onomatope yang menggambarkan pergerakan benda

Tiruan Bunyi pergerakan benda atau dalam bahasa Jepang disebut Mono no Ugoki digunakan untuk menunjukkan pergerakan benda.

Contoh:

ボールがころころころがって、隣の家の庭に入ってしまった。

/Booru/ ga/koro koro/ korogatte/, /tonari/ no/ uchi/ no/ niwa/ni/ haitte/ shimatta/

"Sebuah bola menggelinding dan masuk ke halaman rumah tetangga".

(FBJ, 2013: 154)

6. Onomatope yang menggambarkan keadaan atau karakter benda

Tiruan bunyi mono no youtai/ sheishitsu digunakan untuk menunjukkan keadaan atau karakter benda.

Contoh:

油で手がねばねばする。

/Abura/ de/te/ ga/neba neba/ suru/

"Tangan menjadi lengket karena minyak".

(FBJ, 2013: 146)

7. Onomatope yang menggambarkan aktivitas atau pergerakan manusia

Tiruan bunyi aktivitas atau pergerakan manusia biasa juga disebut hito no douse dalam digunakan untuk menunjukkan aktivitas atau pergerakkan manusia.

Contoh:

池のまわりをぐるぐる回った。

/lke/ no/ mawari/wo/guruguru/ mawatta/

"Anak itu berputar-putar mengelilingi kolam".

(EGG, 1994: 50)

8. Onomatope yang menggambarkan keadaan kesehatan manusia

Tiruan bunyi keadaan kesehatan manusia atau dalam bahasa Jepang disebut hito no kenkou joutai digunakan untuk menunjukkan keadaan kesehatan manusia

Contoh:

風邪のせいか、頭ががんがんして割れそうに痛い。

/Kaze/ no/ se/ ka/, /atama/ ga/gan gan/ shite/ waresoo/ni/ itai/.

"Apakah karena masuk angin, kepala saya berdenyut-denyut dan sakit peserti akan pecah".

(FBJ, 2013: 71)

9. Onomatope yang menggambarkan keadaan hati atau perasaan manusia 
Tiruan bunyi keadaan hati atau perasaan manusia bisa juga disebut hito no yousu/ shinjou dalam bahasa Jepang digunakaan untuk menunjukkan bermacam-macam perasaan yang dirasakan oleh manusia.

Contoh:

きのうは電車がなかなか来なくていらいらした。

/Kinou/wa/ densha/ ga/ naka naka/ konakute/ira ira/ shita/.

"Saya merasa tidak tenang/kesal karena kemarin kereta api tidak datang-

datang".

(FBJ, 2013: 83)

10. Onomatope yang menggambarkan keadaan ciri-ciri fisik manusia

Tiruan bunyi yang menunjukkan ciri-ciri fisik manusia dalam bahas Jepang biasa disebut hito no shintaiteki tokuchou digunakan untuk menunjukkan keadaan ciri-ciri fisik manusia.

Contoh:

まるまると太ったかわいい赤ちやん

Maru maru/ to/ futotta/ kawaii/ aka-chan/.

"Bayi lucu yang benar-benar/ sangat gemuk sekali".

(FBJ, 2013: 69)

\section{Metode}

Pendekatan dan jenis penelitian ini adalah dilakukan menggunakan deskriptif kualitatif karena berupa kata-kata atau gambaran sesuatu. Penelitian ini adalah kata-kata atau gambaran yang mengacu kepada sumber data onomatope berupa bentuk dan maknanya. Dalam penelitian ini yang mewakili hal tersebut terdapat pada 12 video lagu anak-anak berbahasa Jepang. Metode yang diterapkan untuk mengumpulkan data dalam penelitian ini adalah studi kepustakaan dan teknik catat. Penulis menggunakan metode studi kepustakaan dengan mengambil data sekunder dari berbagai penelitian terdahulu dan juga buku acuan yang berhubungan dengan penelitian ini. Data onomatope bahasa Jepang didapat dari 12 video lagu anak-anak berbahasa Jepang.

Teknik catat adalah cara yang dilakukan untuk mencatat data-data yang ada dalam masalah peneliti, kemudian diseleksi, diatur, selanjutnya diklasifikasikan. Langkah-langkah yang ditempuh dalam pengumpulan data, yaitu pertama menentukan sumber data. Sumber data dalam penelitian ini adalah kata onomatope dalam 12 video lagu anak-anak berbahasa Jepang. Langkah kedua, adalah menyimak dengan cara membaca sumber data dan menandai kata-kata yang berkaitan dengan onomatope. Terakhir, data tersebut dicatat kemudian diklasifikasikan berdasarkan bentuk dan maknanya. Instrumen yang digunakan dalam mengumpulkan data yaitu kartu data. Kartu data yang digunakan adalah sebagai berikut.

\section{Hasil Dan Pembahasan}

Berdasarkan permasalahan, teori, metode serta data yang terkumpul, hasil yang didapat dari penelitian ini adalah sebagai berikut.

\section{Bentuk fonologis dan makna onomatope}

Dalam pembahasan ini, secara langsung memasukkan dan menyusun data sesuai kerangka model, menganalisa data onomatope bahasa Jepang. Pengumpulan data pada penelitian ini menggunakan instrumen berupa kartu data dan dianalisis dengan menggunakan metode deskriptif kualitatif. Data yang diperoleh berupa bentuk dan makna yang menunjukkan penggunaan onomatope (giongo dan gitaigo). Hasil penelitian menunjukkan terdapat 16 data yang termasuk giongo dan 8 data yang termasuk gitaigo. Berikut adalah rincian dari data onomatope yang termasuk giongo dan gitaigo. Pertama-tama yang dianalisis berdasarkan klasifikasi dan bentuk onomatope, yaitu giongo giseigo, gitaigo, giyougo, dan gijougo, kemudian bentuk dan makna kata onomatope. Tahap terakhir, analisis yang telah dilakukan langsung ditarik hasil dengan menyimpulkan dalam uraian hasil analisis.

\section{Giongo}

1. Menggambarkan Tiruan Bunyi Benda Lirik :

いそいでリンリンリン

/Isoide /rin /rin /rin/ 
"gemerincing di pagi hari"

\section{Analisis :}

Tiruan bunyi rinrin digunakan untuk menunjukkan tiruan bunyi gemerincing bunyi lonceng kecil kereta Santa, tergambarkan dalam video lagu Awaten bou no santakuroosu di kereta Santa terdapat banyak lonceng kecil seperti pada umumnya yang menjadi ciri khas suara kehadiran Santa bagi yang menantinya disetiap hari Natal tiba. Bentuk tiruan bunyi rinrin adalah hanpukukei yang menunjukkan ungkapan bunyi atau kegiatan yang berulang-ulang / berkesinambungan dan haneruon (Nasal) yang menunjukkan bunyi kata yang menggema juga digunakan untuk menunjukkan bunyi benda yang ringan.

\section{Lirik :}

そらにきらきらおほしさま

/Sora/ni/kira/kira/ohoshi/sama

"Kilau kerlap kerlip bintang di langit"

Analisis :

Tiruan bunyi kirakira digunakan untuk menggambarkan bunyi bintang yang berkerlap-kerlip dilangit sesuai dengan apa yang tergambarkan pada video lagu Omocha no chachacha. Bentuk tiruan bunyi kirakira adalah pemajemukan morfem atau hanpukukei yang menunjukkan ungkapan bunyi atau kegiatan yang berulang-ulang / berkesinambungan.

\section{Giseigo}

\section{Menggambarkan Suara Binatang}

\section{Lirik :}

かえるのうたがきこえてくるよクワクワ

/Kaeru/no/uta/ga/kikoete/kuru/yo/kuwa/kuwa/

"Nyanyian seekor katak akan datang kepadamu, koak koak"

\section{Analisis :}

Tiruan bunyi kuwakuwa digunakan untuk menunjukkan suara katak seperti biasa yang disuarakan pada umumya di Jepang yang tergambarkan jelas pada video lagu Kaeru no gasshou. Bentuk tiruan bunyi kuwakuwa adalah hanpukukei yang menunjukkan ungkapan bunyi atau kegiatan yang berulang-ulang / berkesinambungan.

\section{Lirik :}

$$
\begin{aligned}
& \text { メリーさんの羊メエメエひつじ } \\
& \text { /Merii-san/no/hitsuji/meemee/hitsuji } \\
& \text { "Domba Merry, Domba mengembek" }
\end{aligned}
$$

\section{Analisis :}

Tiruan bunyi meemee digunakan untuk menunjukkan suara domba. Dalam video lagu Merisan no hitsuji tergambarkan seekor domba menunjukkan suaranya ketika Merry memanggilnya. Bentuk tiruan bunyi meemee adalah hanpukukei yang menunjukkan ungkapan bunyi atau kegiatan yang berulang-ulang dan berkesinambungan, termasuk juga terdapat pemanjangan suara (chou'on) pada setiap akhir kata yaitu mee, yang menunjukkan aktivitas dan keadaan yang berlangsung lama, dalam hal ini menggambarkan suara khas domba dalam onomatope Jepang.

\section{Menggambarkan Tiruan Suara Manusia}

Lirik : 
ミックスジュースミックスジュースこいつをググッとのみほせば

/Mikkusujuusu/mikkusujuusu/koitsu/o/gugu'/to/nomihoseba/

"Jus campur jus campur, orang ini terteguk jika meminumnya"

\section{Analisis :}

Tiruan bunyi gugu' digunakan untuk menunjukkan suara tegukan saat meminum jus yang tergambarkan dalam video lagu Boku no mikkusu jyuusu. Bentuk tiruan bunyi gugu' adalah hanpukukei yang menunjukkan ungkapan bunyi atau kegiatan yang berulang-ulang / berkesinambungan, dan merupakan bentuk bunyi konsonan rangkap /Q/ (sokuon), namun tidak berfungsi untuk menunjukkan konsonan rangkap melainkan sebagai penanda sebuah kata, ungkapan atau kalimat yang menyatakan suatu perasaan, ekspresi.

\section{Gitaigo}

\section{Menggambarkan Pergerakan Benda}

Lirik :

どんぐりころころ ドンブリコ

/Donguri/ korokoro /donburiko/

"Sebuah biji menggelinding kebawah dan kebawah"

\section{Analisis :}

Tiruan bunyi korokoro digunakan untuk menunjukkan gambaran suara benda yang menggelinding, dalam video lagu Donguri korokoro menunjukkan keterangan sebuah biji terjatuh dari pohon yang kemudian menggelinding berkali-kali. Bentuk tiruan bunyi korokoro adalah hanpukukei yang menunjukkan ungkapan bunyi atau kegiatan yang berulang-ulang dan berkesinambungan.

\section{Giyougo}

\section{Menggambarkan Aktifitas atau Pergerakan Manusia}

Lirik :

トントントントンひげじいさん

/Tontontonton/hige jiisan/

"Tong tong tong, orang tua berjanggut"

\section{Analisis :}

Tiruan bunyi tonton digunakan untuk menunjukkan suara ketukan tangan, dalam video lagu Tontontonton Hige Jii-san tergambarkan saat seseorang mengetuk kedua tangannya sebagai penanda berubahnya wajah menjadi wajah lainnya. Bentuk tiruan bunyi tonton adalah hanpukukei yang menunjukkan ungkapan bunyi atau kegiatan yang berulang-ulang dan berkesinambungan dan terdapat 2 penasalan suara (haneruon) menunjukkan bunyi kata yang menggema.

Lirik :

ぐーちょきぱーで

/Guu/choki/paa/de/

"Batu, gunting, kertas"

\section{Analisis :}

Tiruan bunyi choki digunakan untuk menunjukkan suara gerakan tangan menirukan bentuk gunting yang tergambarkan jelas dalam video lagu Guu choki paa de nani tsukurou. Bentuk tiruan bunyi choki adalah kata dasar yang hanya terdiri dari dua suku kata.

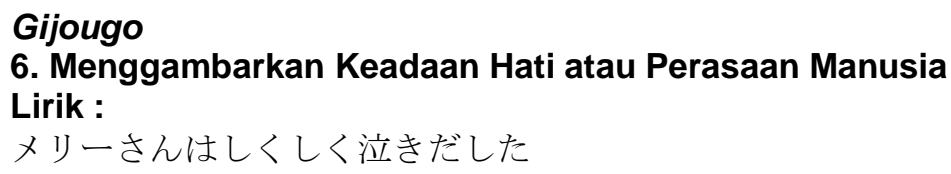


Merii-san/wa/shikushiku/naki/dashita/

"Merry mulai menangis tersedu sedu"

\section{Analisis :}

Tiruan bunyi shikishiku digunakan untuk menunjukkan perasaan hati sedang bersedih, dalam video lagu Meri-san no hitsuji tergambarkan Merry sangat bersedih ketika Guru marah kepadanya, yang melarangnya membawa domba kesekolah yang membuatnya semakin bersedih domba tak bisa menemani Merry disekolah sehingga mereka berpisah. Bentuk tiruan bunyi shikishiku adalah hanpukukei yang menunjukkan ungkapan bunyi atau kegiatan yang berulang-ulang.

Lirik :

先生はかんかんにおこって

/Sensei/wa/kankan/ni/okotte

"Guru sangat marah"

\section{Analisis :}

Tiruan bunyi kankan digunakan untuk menunjukkan perasaan hati sedang marah, dalam video lagu Meri-san no hitsuji tergambarkan seorang Guru sangat marah kepada Merry karena mengajak dombanya kesekolah. Bentuk tiruan bunyi kankan adalah hanpukukei yang menunjukkan ungkapan bunyi atau kegiatan yang berulang-ulang dan terdapat 2 penasalan suara (haneruon) menunjukkan bunyi kata yang menggema.

\section{SIMPULAN DAN SARAN}

Dari 24 data yang sudah ditentukan pada intinya teori Akimoto (2002:136-137) membagi menjadi 7 bentuk onomatope Jepang namun dari hasil analisis hanya terdapat 5 bentuk onomatope Jepang yaitu kata dasar, pemajemukan morfem (hanpukukei), pemadatan suara (sokuon),penasalan suara (haneruon) dan pemanjangan suara (chou'on). Bentuk onomatope yang dominan digunakan adalah hanpukukei, chou'on dan haneruon karena pola bentuk onomatope tersebut menunjukkan ungkapan bunyi atau kegiatan yang berulang-ulang, aktivitas atau keadaan yang berlangsung lama dan menunjukkan bunyi kata yang menggema dalam kehidupan sehari-hari bentuk kata onomatope tersebut sering digunakan.

Kemudian teori Akimoto (2002:138-139) menjelaskan bahwa terdapat 10 klasifikasi makna onomatope dan 5 bagian dari onomatope Jepang namun pada data hanya ditemukan 6 klasifikasi makna onomatope dan sesuai dengan bagian dari 5 jenis onomatope Jepang yaitu (mono o dasu oto) bagian dari giongo, (doubutsu no nakigoe) bagian dari giseigo, (hito no koe/oto) bagian dari giseigo, (mono no ugoki) bagian dari gitaigo, (hito no dousa) bagian dari giyougo dan (hito no yousu/shinjou) bagian dari gijōgo. Makna onomatope yang dominan digunakan adalah (doubutsu no nakigoe) bagian dari giseigo dan (hito no dousa) bagian dari giyougo) karena maknanya menunjukkan suara binatang dan aktivitas atau pergerakan manusia yang sering ditirukan dalam kegiatan sehari-hari.

Dari keseluruhan data ditemukan 24 data onomatope yang dapat dibagi menjadi 6 klasifikasi makna. Data paling banyak ditemukan masuk pada klasifikasi makna tiruan bunyi suara binatang dengan diikuti klasifikasi makna tiruan aktifitas atau pergerakan manusia. Hal ini selaras dengan genre yang digunakan adalah video lagu anak-anak di Jepang yang sangat populer yang termasuk kategori "Japanese Children's Song's" yaitu ceria, gembira, menarik, menyenangkan, mudah diingat, lucu, aktif, ekspresif, fantasi, komunikatif. Dalam genre yang diusung yaitu video lagu anak-anak di Jepang, sering memperagakan gerakan yang aktif hal tersebut banyak aktifitas atau pergerakan manusia yang terjadi dari berdendang bernyanyi, menari, gerakan badan, gerakan tangan dan lain sebagainya.

Onomatope dalam bahasa Jepang memiliki keanekaragaman bentuk dan makna yang begitu luas dan masih menyisakan banyak sekali permasalahan yang belum diteliti. Oleh sebab itu, disaranakn kepada pelajar yang ingin meneliti onomatope untuk menindaklanjuti temuan yang ada dengan melakukan penelitian mengenai bentuk dan makna yang berhubungan dengan bentuk-bentuk onomatope yang lain, atau onomatope-onomatope yang terdapat pada suatu film atau video tidak pada suatu komik atau novel karena sudah sangat banyak penelitian onomatope yang merujuk pada komik atau novel yang cenderung memiliki kekurangan dalam hal mengaudiokan maupun 
mengomunikasikan sehingga ekspresi yang diperagakan terkait onomatope sedikit sulit dipahami dan film / video bisa dijadikan referensi yang lebih variatif bagi peneliti onomatope.

\section{DAFTAR PUSTAKA}

Akimoto, Miharu. 2002. Yoku Wakaru Goi. Tokyo: ALC.

Chaer, Abdul. 2009. Pengantar Semantik Bahasa Indonesia. Jakarta: Rineka Cipta.

Ciptohatono, Anna Maria Ilvi. 2012. "Kesepadanan Bentuk Fonologis dan Makna Bunyi vokal Konsonan Giongo Bahasa Jepang pada Manga Death Note Volume 5 dengan Bahas Indonesia pada Manga Terjemahannya". Jurnal Fakultas IImu Budaya Universitas Dian Nuswantoro Semarang.

Hasada, Rie. 1994. The Semantic Aspects Of Onomatopoeia: Focusing On Japanese Psychomimes. Thesis Master of Arts (Llinguistik) Australian National University.

Kridalaksana, Harimurti. 2008. Kamus Linguistik Edisi Keempat. Jakarta: Gramedia Pustaka Utama.

Maulida, Novi. 2009. Nihon Go No Boin. Kertas Karya Fakultas Sastra Universitas Sumatera Utara Medan.

Panduwinata, O Lydia. 2013. Variasi Makna Dan Penerapan Onomatope Dalam Komik Bakuretsu Utahime 21 Karya Igarashi Kaoru. Artikel Fakultas IImu Budaya Universitas Airlangga Surabaya.

Supangat, Nur Aini Satyani. 2015. "Analisis Kontraktif Onomatope Bahasa Jepang dan Bahasa Jawa." Skripsi Fakultas IImu Budaya Universitas Diponegoro Semarang.

Sarwono, Jonathan. 2006. Metode Penelitian Kuantitatif dan Kualitatif. Cetakan Pertama. Yogyakarta: Graha IImu.

Soviyan, Aden Rahmad. 2018. Analisis Makna Onomatope Dalam Komik "Furizaa Yori Ai Wo Komete." Skripsi Fakultas IImu Budaya Universitas Sumatera Utara Medan.

Sutedi, Dedi. 2004. Dasar-dasar Linguistik Bahasa Jepang (Nihongo Gaku no Kiso). Bandung: Humaniora.

Sutrisna, Tri. 2017. Bentuk Dan Strategi Penerjemahan Onomatope Bahasa Jepang Pada Komik One Piece (Penerjemahan). Skripsi Fakultas IImu Budaya Universitas Diponegoro Semarang.

Verhaar, J.W.M. 2004. Asas-Asas Linguistik Umum. Yogyakarta: Gadjah Mada University Press.

Verhaar, J.W.M. 2010. Asas-Asas Linguistik Umum. Yogyakarta: Gadjah Mada University Press.

Yuniarti, A'tin Nurjanah. 2017. "Analisis Bentuk Fonologis Dan Makna Onomatope Bunyi Glottal Stop." Skripsi Fakultas Ilmu Budaya Universitas Diponegoro Semarang. 